\title{
THE UNIFIED BODY OF CHRIST AS BIBLICAL METAPHOR FOR BEING $\mathrm{CHURCH}$
}

\begin{abstract}
The church, as faith community, is described with the metaphor of one body, with all members interlinked to each other, helping each other, praying for each other, serving each other. The reality is that this church, like the secular community (locally, provincially, nationally, throughout Africa and globally) is divided into class, wealth and health categories. Is this "world-like" fragmented existence of the church depriving her of her unique role as source of hope in a given community? Is she loosing face in the world due to this "world-like" fragmented way of living? Can she better meet the social challenges, related to poverty and HIV, if, as alternative community, rich and poor were indeed living as one body? How would she then define and respond to poverty and HIV infection?
\end{abstract}

\section{INTRODUCTION}

Ministering in both an affluent community and one of the poorest municipalities in South Africa, I am placed in a prophetical-critical position from where I ask questions about being church in such a divided world, where some members of this body live an abundant life and others suffer with insufficient food and medical security.

The narrative-reflective method is selected as method of investigation. By using this method, the researcher examines life, reflecting on what one sees, assigning meaning and values to events and people. Narrative research is the study of how human beings experience the world, and the narrative researcher collects these stories and writes narratives of experience. This method of research is gaining ground in socio-educational fields (Moen 2006).

Dr. Lourens Schoeman, Guest Lecturer, Department Missiology, UFS. E-mail: Igschoeman@telkomsa.net.

Acta Theologica 
The church, as faith community, is described as one body, under one Head, with one baptism, one Spirit and one calling. There are very clear expectations that the members would pray for each other and carry each other's burdens. This being the ideal, the reality is that the church exists within an all-high Gini coefficient, ${ }^{1}$ with extreme poor and rich living in the same town and country, and on the same continent and planet.

Due to limited access to appropriate health services, the poor reflect a higher HIV infection rate that turns into full-blown Aids. This line of division within the community runs throughout the church. Within the smallest village, town, city, district, province, country, continent and the global village the church, as faith community, resembles the secular community: fragmented and divided on the basis of income, class and consequently health care-related issues.

If one dares to view the inequalities where the church exists, and one follows the body metaphor of the church, defining an alternative lifestyle within the faith community and acknowledging the interconnectedness of these communities, would new hope-generating energy be released? Will the church appear and talk differently about poverty and HIV infection? Would attempts to address these social evils be different? Would interdependence cause these groups to talk differently about each other, God, faith, life and society?

\section{A WORLD OF INEQUALITY}

\subsection{The poor}

The Human Development Index ${ }^{2}$ is a composite statistic used to rank states, countries, municipalities, cities and villages by level of "human development". Human development is a measure of human (especially child) welfare, expressed in categories of life expectancy (health services), literacy (education services) and income (standards of living). It is used to distinguish whether the country/community is a developed, a developing or an underdeveloped country, and to measure the impact of economic policies on the quality of life.

In the district where I minister, there are communities with a low Human Development Index. Most people in these communities are pre-modern in terms of development (subsistence farming preferred), medicine (traditional

1 Gini coefficient measures the gap between the rich and the poor in a specific community.

2 http://en.wikipedia-org/wiki/HumanDevelopmentIndex. 
healers dominate over local clinic advice, e.g. re TB), democratic politics (elected ward counsellors become like chiefs with little accountability), and education (preferred low literacy). They are mostly dependant on social grants. HIV infection in these communities is among the highest in the country. There is a clear link between income levels and the devastating effects of HIV on health. The poor are becoming poorer and sicker. And the poorest of the poor become younger, with growing child-run households.

The major part of the poorer community associates with the late prophet, Shembe, now succeeded by a brother's son. He is super rich. He offers presumed quick fixes for unemployment, Aids, TB, family feuds and legal matters. Syncretism and Old Testamental legalism are popularising this religious movement: Twenty litres of blessed water or a bottle of blessed Vaseline is guaranteed to solve problems, at a minimal cost, much cheaper than a visit to a private medical doctor. Our local hospital is known for its corruption and high baby mortality. Poor patients, not accessing medical aid, are often treated in a most undignified manner. The poor know that without medical insurance life consists of high health hazards. Shembe offers an affordable way to negotiate the intervention of the spiritual superpowers of ancestral spirits and God, in order to make life more bearable.

Due to the fragile nature of the poor populations, people are linked to one another through extended family systems. Communities are sandwiched, with breadwinners, en route to a better life, taking dual responsibility for both offspring and parents. Funerals and family gatherings are major events in keeping this system alive. There is a vibrant life and interconnectedness in the poor communities (Dlamini 2009:95-101).

\subsection{The rich}

In our town there are also middle-class and rich communities. The middle class mainly consists of highly paid government officials and politicians. The economy of the town is mainly in the hands of a small elite (mostly European, Muslim, Chinese and Hindu communities, who only represent $8 \%$ of the community at large). Many effective factories that are owned and managed by this small group of elite supply work and income to thousands of people. Our town paper, the Ladysmith Gazette (31 March 2011), reports on incompetent municipal water engineering that causes huge losses in the industries, threatening to close down if the situation is not addressed. Imports of textiles from Asia are closing down large textile industries, causing unemployment. After social grant pay-out days, the poor flock to town and spend their grants in the shops of the elite, going back home with no cash in their pockets. 
The richer community is often self-concerned, materialistic, individualistic, apathetic, and their religious activity is absorbed to a greater extent by the desire to manipulate the supernatural for the sake of their own prosperity and wealth. Their being in an economically favourable situation is viewed as godly intervention and pre-destination, with the implication of exclusion of those in poor communities, who are still in the dumps because they messed up the relationships with the spiritual world of ancestor spirits, gods, angels and holy saints. American prosperity religion beams over the TV, reassuring wealth in the name of God.

When someone manages to "upgrade" from downtown, getting employment and accommodation in uptown, ties with downtown are broken. Only family ties remain. Little role-modelling and reinvestment in downtown occurs. There is a one-way ticket from downtown to uptown.

Two time zones? Two worlds? Two planets? Two solar systems? With a one-way ticket from planet downtown to planet uptown? Rich and poor. Educated and illiterate. Healthy (with life expectancy of 80 years and access to superior private health services) and chronically ill (with life expectancy of less than 45 years). Some with clean, running water and others depending on high-risk cholera-infected water sources. Some accessing the electric supply grit of a dysfunctional, expensive para-statal supplier. Others lured into political loyalty by service deliveries.

\subsection{Class division is outgrowing race divisions}

In the new South Africa the Radical-Liberal debate was asking for the causes of division in the community: Was it European racism (Afrikaner frontier) (liberal point) or class conflict (radical point) (Duminy \& Guest 1989)? In the new South African town class becomes a unifying power, bridging race in the workplace and churches, still excluding the poor from uptown communities.

\subsection{A global phenomenon}

All of these people live in our town. Our town is typical of the bigger global village. The division we live with is common throughout our country, our continent Africa, and our planet. Our town is typical of the bigger global village. Historical, social and political causes may differ, but the division is global. 


\subsection{The line of division runs through the church}

Martin Luther King Jr. said that in America, 11:00 on Sunday morning is the most segregated hour of the week (McNeil 2008:9). In the global village, throughout the world, Christians, like all other people, live out a "consciousness of kind" in terms of social class, education and cultural identity. We feel comfortable with people whom we find to be like ourselves, meeting and socialising in "homogeneous units". Birds of the same feather flock together. This is normal, universal human nature. The tendency for class and income to flock together transcends cultural and language barriers. This is visible in both black and white faith communities in our town.

\subsection{Common brokenness among the rich and the poor?}

Corbett and Fikkert (2009:84-90) view the root of the above problem in a broken worldview, among both rich and poor.

- Both are broken in their understanding of a graceful, loving, caring God.

- Both are broken in terms of their self-understanding. Both do not understand who they were created to be. Some have a "god complex" and others have an inferiority complex.

- Both are broken in their relationship and understanding of other human beings, in terms of respect and acknowledgement of the other. They are not interlinked.

- Both are broken in terms of their relationship to creation. Some abuse and over-consume natural resources and others are estranged from the life-sustaining blessings that are found in creation, and are not even able to plant a patch of vegetables.

This brokenness of the faith community in both the wealthy and the poor part of the body elicits the following questions:

- Could the two parts perhaps assist each other in healing, becoming more whole human beings?

- Can the two parts of the body assist each other in understanding God better?

- Can the two parts of the body perhaps help each other to understand the social dynamics between rich and poor better? 
- Can the two groups perhaps help each other to be better stewards of creation?

- Would we talk differently about poverty and HIV infection, if it were an "us" thing, and not a matter of "us and them"?

\section{THE BODY METAPHOR: CHRIST'S UNITED BODY}

The body metaphor describes the church as one body, with many members, not having the same function, but interlinked as members of each other. Different gifts were given to the different members in the church, whereby they must serve, teach, encourage, lead and help the others (Romans 12:38). As body of Christ each member has unique gifts and functions, but they function as a unity, even if some are slaves and others are free. They are baptised with the one Spirit. They are interdependent, the one needs the other. Those who seem to be weak are of utmost importance. Those who are unattractive are clothed with more care. And so, in this body there is no division, but all its different parts have the same concern for one another. If one part of the body suffers, all the other parts suffer with them, and if one part is praised, all the other parts share in its happiness (1 Cor. 12:1-31). ${ }^{3}$

Is the current division within the church, on the basis of class and income, challenged by the body metaphor, or does the body metaphor only apply to one homogeneous neighbourhood, as is typically preached in congregations?

What would happen if the church interpreted the body metaphor as paradigm for her existence in this diversified world? What if rich and poor were interlinked to each other, serving, teaching, encouraging, leading, embracing, protecting and clothing each other with honour, being happy for the other's successes? Would the church have more credibility? Would the church as giver of hope be stronger to challenge inequalities and injustices? Would the church then continue to turn a blind eye to injustices, requiring a prophetic voice?

Does the body metaphor put the church in an advantageous position in eradicating poverty and HIV infection? Will she be more effective in this venture?

\subsection{Challenges}

Biblical ethics, however, often challenge the church to be different, and strangely unique in terms of "normal", human, "fleshly", natural behaviour.

3 Free translation. 
The question then is: Does the body metaphor challenge the church in a polarised world to be different? Is the church true to her being, when she comfortably opts for a normal segregated life within the global village? Especially seen in the light of an all-high Gini coefficient and HIV infection rate? Some church characteristics challenged by the body metaphor are:

- The interpretation of the á $\lambda \lambda \hat{n} \lambda \omega \mathrm{v}$ "to one another" - imperatives. Often these imperatives are applied only within the smaller homogeneous group, blinding the group for the "others" outside, their needs and their future (Mofokeng 1990)

- The division between "a-political", spiritual matters and secular, worldly matters. This spirituality leads to a silent disguise of own privileged positions (Burger 1997) and creates blind spots in terms of justice issues.

- Confusion in the answer as to who is the subject and who is the object in poverty and HIV eradication. Does the "lesser" part of the body (who are they?) have no potential to pull themselves up by their own shoestrings? Are both groups not equally broken? Do both need healing and growth, and do they need each other to obtain this growth? Is the solution elsewhere than either poverty or riches? (Mbeki 2009) Is it not more an issue of dual stewardship?

- A concentric circled thought on rendering services: Charity begins (and often ends) at home, and the leftovers are used for "them", the "outsiders". The implication is that poverty and HIV eradication is never exceptionally high on the uptown church agenda. It is a "nice to have" if there is money left after upholstering the pews.

- The poor part of the body is always reminded that the mission purpose of the richer churches was to establish self-supporting churches, growing independent from the richer sending church. The missional aim is that even in one town the "mother" church and "daughter" church must exist independently from the other, never together as one church. Many missional conferences examine ways in which the poor part of the body can effectively be amputated from the rich part. The body metaphor emphasises dual responsibility and caring for the weakest part more specifically.

- Aid is often rendered by paid NGOs established by uptown communities "to save" downtown communities. Non-paid members of the body (in both uptown and downtown) are often not involved. Large budget contributions come from state subsidies and Lotteries. Church deacons, some with entrepreneurial skills, often just gather the 
offerings to maintain inward focusing church structures. Their skills are not regarded as a valued asset of the body at large. In the church the workplace is seldom viewed as extended place of ministry. Skills development is not regarded as ministry. Members with skills are not considered to be ministers in the context.

- The stewardship of the rich is not challenged by exposing them to real contextual needs in the same community.

What can happen when the church in my town and the global village will begin to function as a unified body, under one Head, Jesus Christ?

\subsection{Advantages of the church being one united body}

The body metaphor, as emphasised in Rom. 12: 1-8; 1 Cor. 12: 1-31 and Eph. 4: 9-16, puts the church in an advantageous position to combat poverty and HIV infection.

- Diversity is acknowledged. The body parts are not all the same. The bigger vision is not unrealistic uniformity, but acknowledging each one's unique gifts, position and function. If this is true of a local congregation, can it be true of the church in one town? Can it be true of the global village?

- In this diverse body, each member (on different sides of the railway line and ocean) has an important role to play, which cannot be played by another member. The rest of the body needs the other for their unique contributions. The members are interdependent. One without the other is incomplete. The rich can teach the poor, but the poor can also teach the rich.

- Members are interlinked. When one member suffers, the whole body is affected. When one part has Aids, the body has full-blown Aids. When one part is poor, the whole body sleeps restless at night. Combating these life-robbing forces of evil is the prime priority of the whole body. Church prime work forces, prime budget, prime energy is spent on the war against poverty and HIV infection. This is regarded as part of Kingdom ministry and not as a secular "nice to have", because it affects "us" all, and not the unknown "them".

- The body works toward a new dream: The coming Kingdom. It is not left to government, but government is held accountable, especially where government is the "architect of poverty" (Mbeki Mo 2009). The church has its own unique contribution to make: To re-ignite hopes as 
the engine of social transformation. Hope is needed to mobilise action. Without hope and a dream a community can never stand up. Poverty is considered an anti-Kingdom phenomenon, but also selfishness and apathy. HIV and Aids is also anti-Kingdom, but also the lack of health services in some communities. The combined Kingdom focus asks for a new light, a new sign of hope to be erected in the global village. The focus is not on the negative anti-Kingdom phenomena, but on something new and hopeful that is emerging from the involvement of a life-generating God.

- Eph. 4 emphasises the offices of the church as having the task to build the body in love. Each member of the body plays a part in bringing about the signs of the Kingdom. Equipment of the whole body becomes a fixed item on the church agenda. All members, and not only offices and structures, are focused on eliminating poverty and HIV infection. In this combined focus the church as body is united. Unity under one Head, drenched by the same Spirit links rich and poor in a bigger Kingdom goal.

- It was this very hope-generating, alternative, strange lifestyle of Christians in the first church that caused a positive attitude from the outsiders, causing the obscure, marginal Jesus movement to become the dominant religious force in the Western world in a few centuries (Stark 1996).

- Giving the weakest member an honourable position. Neither poor nor rich is not sinful. Having Aids is not sinful; neither is growing old healthy and well cared for. How does the body take care of the poor? How does the body take care of the rich? How do we cover up each others' weakness? How do we heal each other's' weakness? How do we grow together into more mature, God-like images? Becoming more like the Head? Perhaps we see a successful business person, helping a brother or sister in starting a business in downtown, battling through all the pains, learning about the unjust hindrances, and getting ways around it? The uptown business person will definitely grow into fuller maturity, as well as the downtown person. Who is the weakest member?

- Love (1 Cor. 13) forms the generator of energy in this venture. "He aint heavy, he is my brother" ${ }^{\prime \prime}$ is a different motivator than class equality, economic unrealism or political abuse of imbalances. Chester (2004:176) states that we do not help the poor, because we 
want to move humanity closer to a poverty-free utopia, but we help the poor, because they are fellow human beings whom we love. This love-generated action is everywhere, often in small gestures and simple actions, denting unjust systems, spreading a lovely aroma in unexpected places.

- The Christian faith community cannot define itself without being merciful. A life poured out in deeds of mercy is the inevitable sign of true faith. In its being the church as body cannot ignore poverty and HIV/Aids challenges.

\subsection{The unique position of the church as body can make a bigger difference in the world}

The church as united body in this divided global village is uniquely positioned to play a prominent role in combating poverty and HIV infection. Stark (1996) is convinced that the early church's unique composure and social roles was one of the contributing factors in establishing the church as a major role player in forging an alternative community in Europe. Can it happen today as well? Can the church today, in its involvement in the prevention of poverty and HIV infection, still play such a role, contributing to the credibility of Christianity?

The Barna institute (Kinnaman 2007), investigating community attitude towards the church, sees a lack of trust in the church in America, due to a lack of credibility and involvement with social problems. The church is regarded in this research as a judgmental, self-focused institution, with little relevance to society at large. Only paid members benefit. Can the church as body again have a unique role in resetting the table in poor communities? Can the church again be a credible witness of the Ebed Yahweh (the Servant of the Lord)?

Can Bonhoeffer's (1954) dream of a life together in Christian fellowship be a dream for the global village, where rich and poor praise together, study Scriptures together, sing a new song, in meekness, by listening, by helping, in a ministry of bearing burdens, and authority?

After September 11, Bill Clinton stated:

We have to build the pool of potential partners and reduce the pool of potential terrorists. Most important, we must make the world a home for all its children (Mills 2002). 
Is the church not perfectly positioned to form these pools of partners? More than partners: Brothers and sisters.

Tim Chester (2005:166) talks of integral mission as mission WITH the poor, empowering poor communities, working community based, integrating different fields. He examines church-based rural development in Rwanda, and mobilising church response to HIV/Aids in Zimbabwe. $\mathrm{He}$ includes advocacy and lifestyle of humility in the church's calling, the rights of the poor and macro-policy change. The church with a Kingdom vision of "on earth as it is in heaven" is positioned for such an integrated mission in their town/city. He talks of sharing the Good News to the poor through social involvement. This brings good news to both rich and poor, welcomes the excluded, strengthens the weak, and follows the crucified Lord. He asks: Can we make a difference? And the answer is: If I had a pound for every time I have heard someone tell us that we can make a difference, I think I could personally end world poverty. Yet, he is cautious of oversimplifying the aim to eradicate poverty.

Korten (Chester 2004) identifies 4 phases of development in thought on poverty ministries:

1. Short-term humanitarian assistance.

2. Small-scale local development.

3. Advocacy, influencing unjust and inequitable policies.

4. Indigenous civil society where people movements in indigenous communities are the goal.

Each of these phases came with its own optimism, but in global terms all the talking and working in the past 50 years has not solved the problem of poverty. Why? Sin (or human brokenness) is universal. The exploited will ultimately become the exploiter. They are not morally superior beings. $\mathrm{Sin} /$ brokenness is universal; it is within the rich and the poor. And sin/ brokenness is deep, it penetrates our cultures, our social, economic and political systems. Can we then be optimistic about the Christian response to poverty and HIV/Aids? Is the solution only in the future with the second coming of the Lord? Has the church made significant impact on poverty and HIV/Aids? 


\section{CONCLUSION}

The power of the Gospel leads to transformation in all areas of life, but it can only transform communities if it starts within us as Christians. The Christian faith community needs to search, struggle and break out of cultural and class-bound thought patterns, in order to minister this transformation to the community. Viv Grigg (2004:1) views the church as prophets who have an inner compulsion to act out their prophecies symbolically. Their lives then become cameos of truth, frescoes painted across the wall of grotesque evil. The cameos then become written parables. Perhaps this is the biggest challenge to the global Christian faith community today: Ourselves becoming transformed. From within, re-joining the amputated members of the body into one functional body, bound together by the Spirit of God, serving in love.

\section{BIBLIOGRAPHY}

Blomberg, C.L.

1999. Neither poverty nor riches: A Biblical theology of possession. Illinois: IVP.

BONHOEFFER, D.

1954. Life together: A discussion of Christian fellowship. San Francisco: Harper \& Row. (Translated by Doberstein, J.W.)

Burger, C.

1997. Christene en hulle geld. Die Kerkbode 158(10), p. 14.

Chester, T. (ED.)

2005. Justice, mercy and humility: Integral mission and the poor. Bletchley: Paternoster.

Chester, T.

2004. Good News to the poor. Nottingham: IVP.

CORBETt, S. \& FIKKERT, B.

2009. When helping hurts. Chicago: Moody Publishers.

DLAMINI, J.

2009. Native nostalgia. Auckland Park: Jacana Media.

Duminy, A. \& Guest, B.

1989. Natal and Zululand: From earliest times to 1910. A new history. Pietermaritzburg: UKZN Press Shuter \& Shooter.

GrIGG, VIV.

2004. Companion to the poor: Christ in the urban slums. World Vision. 
Kinnaman, D.

2007. UnChristian: What a new generation really thinks about Christianity... and why it matters. Grand Rapids, Michigan: Baker Books.

LADYSMITH GAZETTE

2011. Water supply. 31 March.

MBEKI, M.

2009. Architects of poverty: Why African capitalism needs changing. Johannesburg: Picador.

McNeIL, B.S.

2008. A credible witness: Reflections on power, evangelism and race. IVP Books Madison.

MiLLS, G.

2002. Poverty to prosperity: Globalisation, good governance and African recovery. Cape Town: Tafelberg.

Moen, T.

2006. Reflections on the narrative research approach. International Journal of Qualitative Methods, 5(4), December. [Online] Retrieved from http://www. ualberta.ca/-iqqm/backissues/5_4html/moen.

Mofokeng, T.A.

1990. The task of the church in the transitional period especially with regard to poverty. DRCA Action. Supplement 2:1-5.

STARK, R.

1996. The rise of Christianity: How the obscure, marginal Jesus movement became the dominant religious force in the western world in a few centuries. New York: HarperCollins.

Keywords

Church as one body

Rich

Poor

Credible sources of hope
Sleutelwoorde

Kerk as een liggaam

Ryk

Arm

Betroubare bronne van hoop 